\title{
THE EFFECTS OF AMINE-CARBOXYBORANE RELATED DERIVATIVES ON UMR-106 BONE METABOLISM
}

\author{
Margaret E. Murphy ${ }^{1}$, Amy L. Elkins², Robert P. Shrewsbury ${ }^{1}$, Anup Sood ${ }^{3}$, \\ Bernard F. Spielvogel ${ }^{3}$ and Iris H. Hall ${ }^{\star 2}$ \\ 1 Division of Pharmaceutics, 2 Division of Medicinal Chemistry and Natural Products, School of Pharmacy, \\ University of North Carolina, Chapel Hill, North Carolina 275559-7360, USA \\ 3 Boron Biologicals, Inc., 620 Hutton St., Suite 104,Raleigh, North Carolina 27606, USA
}

\begin{abstract}
The amine-carboxyboranes and related derivatives have been shown to be potent anti-inflammatory and anti-osteoporosis agents. Their action in part appears to be mediated by the modulation of cytokines, e.g. TNF $\alpha$ or IL-1. Previous studies have demonstrated that LPS induced macrophages release of TNF $\alpha$ maximally at 60 to $90 \mathrm{~min}$. and IL-1 from 5 to $8 \mathrm{hr}$. The amine-carboxyboranes reduced significantly the release of these cytokines but also blocked TNF $\alpha$ high affinity binding to UMR-106 receptor at $90 \mathrm{~min}$. at $10 \mu \mathrm{M}$, and $\mathrm{IL}-1$ high affinity binding at $5 \mathrm{hr}$. at $12.5 \mu \mathrm{M}$. In addition, the agents suppressed IL-8 binding to CHO K1 high affinity receptor at $24 \mathrm{hr}$. at $50 \mu \mathrm{M}$ and IL-2 binding to HuT-8 receptors at $25 \mu \mathrm{M}$ at $90 \mathrm{~min}$. and $5 \mathrm{hr}$. Correlation of metabolic events associated with osteoporosis showed that at $90 \mathrm{~min}$., when TNF $\alpha$ receptor binding was reduced by the agents, calcium uptake into UMR-106 cells was reduced at $10 \mu \mathrm{M}$ as well as the acid and alkaline phosphatases, and the prostaglandin cyclo-oxygenase activities and adhesion of leukocytes and macrophages to UMR-106 cell monolayers. At $5 \mathrm{hr}$. when the agents reduced IL-1 binding to UMR-106 receptors, calcitonin and 1,25-dihydrovitamin $\mathrm{D}_{3}$ binding was reduced by the agents as was acid and alkaline phosphatase, and 5'-lipoxygenase activities and white blood cell adhesion. At this time calcium uptake and proline incorporation was increased significantly by the agents. At later times e.g. 18-48 hr. calcium uptake was still increased, and NAG activity was inhibited in the presence of the agents. These effects may be related more to the inhibition of other cytokine receptor binding, e.g. IL-8. Thus, many of the observed metabolic effects of amine-carboxyboranes as antiosteoporosis agents can be correlated with their inhibition of cytokine high affinity binding to target cell receptors.
\end{abstract}

\section{Introduction}

Selected amine-carboxyborane derivatives at $8 \mathrm{mg} / \mathrm{kg} / \mathrm{day}$ have been shown to prevent osteoporosis and loss of bone mass in rodents[1]. In vitro studies with $\mathrm{CF}_{1}$ mouse pups calvaria and rat UMR-106 osteosarcoma cells have shown that these compounds over $48 \mathrm{hr}$. reduce the loss of calcium from the cells better than calcitonin and simple boron salts[1]. Indications from the previous in vivo and in vitro studies were that the 
amine-carboxyboranes effectively lowered $T N F \alpha$ and $I L-1$ release from macrophages $[1,2]$ which is asociated with a lowering of hydrolytic and proteolytic enzyme activities and secondary chemical effects from prostaglandins and leukotirenes released at the sites of inflammation [3,4] and of bone osteoporosis[1]. The previous studies did not attempt to correlate the incubation time of the drugs with the maximum released of the cytokines into the medium. The present study has been performed in rat UMR-106 bone cells at times, i.e. $90 \mathrm{~min}$. and $5 \mathrm{hr}$, which have been shown to be the time periods of maximum release of cytokines, TNF $\alpha$ and IL-1, from macrophages. These time points were selected so that we can determine the direct effect of those cytokines on specific biochemical events of bone metabolism. The selected compounds at $8 \mathrm{mg} / \mathrm{kg} /$ day orally have been shown in vivo in lactating ovariectomized rats to significantly elevate femur and humerus volume, weight, density and ash weight after 14 days[1]. Also, serum calcium and femur calcium levels were elevated whereas hydroxyproline levels were reduced in rodents by the amine-carboxyboranes.

\section{Methods and Materials}

The amine-carboxyborane derivatives were previously synthesized and the chemical and physical characteristics reported[1]: Compound $\frac{1}{3}$ $\left(\mathrm{C}_{6} \mathrm{H}_{5}\right)_{3} \mathrm{PBH}_{2} \mathrm{COOH}$, Compound $\underline{2} \mathrm{C}_{16} \mathrm{H}_{33} \mathrm{~N}\left(\mathrm{CH}_{3}\right)_{2} \mathrm{BH}_{2} \mathrm{COOH}$ and Compound $\underline{3}$ $\left(\mathrm{CH}_{3}\right)_{3} \mathrm{NBH}_{2} \mathrm{COOCH}_{3}$. TNFa, IL-1, IL-2, IL-8 and the standards were purchased from Sigma Chemical Co.

Cell Maintenance

Rat UMR-106 osteosarcoma cells (DMEM + 10\% fetal calf serum (FCS) + penicillin/streptomycin [P/S]) and IC-21 mouse macrophages (RPMI $1640+$ 10 \& FCS $+\mathrm{P} / \mathrm{S}$ ) were grown to confluency[1]. Mouse macrophages (J774 A) were maintained in DMEM $+15 \%$ FCS $+\mathrm{P} / \mathrm{S}$; human peripheral leukocytes (RPMI 1788) were maintained in RPMI $1640+15 \%$ FCS + P/S. Chinese hamster ovaian ( $\mathrm{CHO}$ ) $\mathrm{K} 1$ cells were maintained in EMEM + 10\% FCS + nonessential amino acids $+\mathrm{P} / \mathrm{S}$. HuT-8 cells human cutaneous $\mathrm{T}$ cell lymphoma were maintained in RPMI + 108 FCS + gentamycin/kanamycin.

High Affinity Binding to Receptors on UMR-106 Cells

Two $\mu \mathrm{Ci}$ of ${ }^{125} \mathrm{I}-\mathrm{TNF} \alpha$ (human recombinant, $30 \mathrm{mCi} / \mu \mathrm{g}$ New England Nuclear) or $125 \mathrm{I}-\mathrm{IL}-1 \quad(70-120 \mu \mathrm{Ci} / \mu \mathrm{g}$, New England Nuclear) was added to confluent UMR-106 cells for 30 to $120 \mathrm{~min}$ with the amine-carboxyboranes from 10 to $50 \mu \mathrm{M}$ [5]. 125 IL-8 [2 $\mathrm{Ci} / \mathrm{mol}$, Amersham] was added to confluent CHO KI cells for 5 to $24 \mathrm{hr}$. and $125 \mathrm{IL}-2$ [20-50 $\mu \mathrm{Ci} / \mathrm{ug}$, New England Nuclear] was added to confluent HuT-8 cells from 5 to $48 \mathrm{hr}$ with drugs. All of these cells have high affinity receptor within their plasma membrane for the specific cytokine. After the allotted time period, the medium was decanted gently and the cells were washed $6 \mathrm{X}$ in cold isotonic PBS, $\mathrm{pH}$ 7.2. The cells were taken up in $0.1 \mathrm{~N} \mathrm{NaOH}$ and aliquots were counted. $125 \mathrm{I}$-Calitonin (human, $2000 \mathrm{Ci} / \mathrm{nmole}$, Amersham) or $3 \mathrm{H}-1,25$-dihyroxyvitamine $D_{3}$ (155-175 $\mathrm{Ci} / \mathrm{mmole}$, New England Nuclear) $10 \mu \mathrm{Ci}$ were added to confluent UMR-106 cells with drugs from 10 to $100 \mu \mathrm{M}$ and incubated 90 min. or $5 \mathrm{hr}$. Cells were washed repeatedly in PBS and take-up in $0.1 \mathrm{~N}$ $\mathrm{NaOH}$. In the case of 1,25-dihydro-vitamin $\mathrm{D}_{3}$, the nuclei preparation was obtained. The aliquots were counted in a Pachard Beta counter corrected for quenching, and non-specific binding of isotopes.

${ }^{45} \mathrm{Ca}$ Uptake and ${ }^{3} \mathrm{H}$ Proline Incorporation into Collagen of UMR-106 Cells ${ }^{45} \mathrm{CaCl}_{2}$ ( $0.2 \mathrm{mCi}$, New England Nuclear) was added to confluent UMR 106 , The medium was decanted and the cells were washed 4 times with PBS, pH 


\section{A. Sood, B.F. Spielvogel and I.H. Hall}

$7.2[6,7]$. The cells were taken up in $0.1 \mathrm{~N} \mathrm{NaOH}$ and counted $[24,25]$. Rat UMR-106 cells (95\% confluent) were incubated with $1 \mu \mathrm{Ci}$ of $2,3,4,5-$

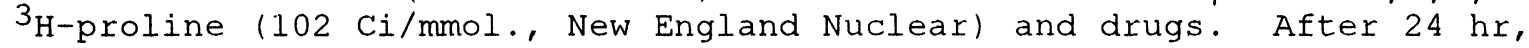
the medium was discarded and the cells were washed repeatedly with PBS. The cells were harvested in $0.1 \mathrm{~N} \mathrm{NaOH}$. After treatment with $208 \mathrm{TCA}$, cells were centrifuged at $3500 \mathrm{~g} \times 5 \mathrm{~min}$. The supernatant was discarded and the pellet was suspended in $1 \mathrm{ml}$ of $50 \mathrm{mM}$ Tris $+5 \mathrm{mM} \mathrm{CaCl} 2+20 \mu \mathrm{l}$ of collagenase (10 mg/ml buffer, Sigma Chemical Co. [St. Louis, MO]) and incubated for $2 \mathrm{hr}$ at $37^{\circ} \mathrm{C}$. Tannic acid:TCA (5\%) [1:1] solution was added and incubated for $15 \mathrm{~min}$ at room temperature followed by centrifugation to separate the collagen from non-collagen protein[8].

Lysosomal Enzymes

UMR-106 cells $\left[10^{8}\right]$ were grown to confluency and incubated for $90 \mathrm{~min}$. or $5 \mathrm{hr}$. with drugs at $12.5,50$ and $100 \mu \mathrm{M}$. Acid and alkaline phosphatase activities were determined using $0.1 \mathrm{M} \beta$-glycerolphosphate in $0.1 \mathrm{M}$ acetate buffer, $\mathrm{pH} 5.0$ and 8.5 , respectively[1-3]. Total enzyme was released with Triton $\mathrm{X}-100$. The reaction was terminated with 10\% TCA and then the solution was centrifuged at $3500 \mathrm{~g}$ for $10 \mathrm{~min}$. The inorganic phosphate in the supernatant was determined spectrophotometrically at $800 \mathrm{~nm}$ by the method of chen et al. [9]. NAcetylglucosaminidase [NAG] activity was determined by the method Tulberg-Reinert and Hetti[10]. UMR-106 cells were incubated with drugs at $12.5,50$ and $100 \mu \mathrm{M}$ for $90 \mathrm{~min}$. and $5 \mathrm{hr}$. in the presence of $10 \mu \mathrm{g} / \mathrm{ml}$ LPS (Salmonella abortus equi). The medium [50 $\mu l]$ was incubated with 7.5 $\mathrm{mM}$ p-nitrophenyl-N-acetyl- $\beta$-D-glucosaminide in glycine buffer, $\mathrm{pH} 5.0$ in 96-well microplates. The reaction was stopped by the addition of glycine/EDTA buffer [50mM:5mM]. The concentration of p-nitrophenol released was measured at $405 \mathrm{~nm}$ using a microplate reader [Thermomax, Molecular Devices Corp.].

Prostaglandin Synthetase Activity

The incubation procedures of Tomlinson et al.[11] and Glatt et al. [12] were used to determine prostaglandin formation from ${ }^{3} \mathrm{H}(\mathrm{N})$-arachidonic acid (100 Ci/mmole) and UMR-106 cells $\left(10^{6}\right)$. After $1 \mathrm{hr}$, the reaction was terminated with $2 \mathrm{~N} \mathrm{HCl}$ and the mixture was extracted with ether and evaporated. The residue was dissolved in ethyl acetate and applied to silica gel TLC plates which were eluted with chloroform, methanol, water and acetic acid (90:8:1:0.8). The plates were developed with iodine vapor and the area appropriate to the prostaglandin standards was scraped and counted $[12,13]$. The dpm in each area was calculated as percent of the total dpm applied to the plate.

5'-Lipoxygenase Assay

UMR-106 cells were incubated for $30 \mathrm{~min}$ with phosphate buffer (pH 7.2) containing $0.6 \mathrm{mM} \mathrm{CaCl} 2$, and $1.0 \mathrm{mM} \mathrm{MgCl}_{2}$, $10 \mathrm{mg}$ Calcium Ionophore $\mathrm{A} 23187$ and $1 \mathrm{mCi}{ }^{14} \mathrm{C}$-arachidonic acid $\left(100^{\prime} \mathrm{Ci} / \mathrm{mmol}\right)$. The reaction was terminated with 2 volumes of EtOAC: $\mathrm{CH}_{2} \mathrm{Cl}_{2}$ containing $12 \mathrm{mg}$ cold arachidonic acid. The organic phase was evaporated to a residue which was applied to silica gel plates. The plates were eluted with chloroform:methanol:water:acetic acid (90:8:1:0.8). The 5-HETE area corresponding to the standard was scraped and counted[13,14].

Cell Adhesion to UMR-106 Cells

RPMI 1788 leukocytes or J774.A1 mouse macrophages [108] cells were

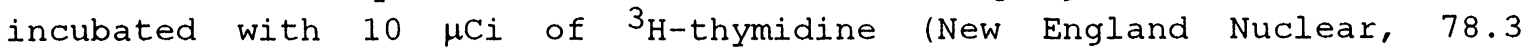
$\mathrm{Ci} / \mathrm{mmole}$ ) for $3 \mathrm{hr}$. and growth medium $[15,16]$. The cells were centrifuged at $1000 \mathrm{rpm}$ for $5 \mathrm{~min}$, rinsed in isotonic PBS, $\mathrm{pH} 7.2$ and 
resuspended in fresh medium. Aliquots of labeled cells were added to confluent UMR-106 cells and the drugs were added at 25, 50 or $100 \mu \mathrm{M}$ and incubated for $1.5,2$ and $5 \mathrm{hr}$. The medium was decanted and the UMR-106 cells were washed repeatedly with PBS. The cells were taken up in $0.1 \mathrm{~N}$ $\mathrm{NaOH}$ and aliquots were counted.

\section{Results}

Preliminary studies have demonstrated that IC-21 macrophages when incubated with LPS [E. Coli] at $10 \mu \mathrm{g} / \mathrm{ml}$ release $\mathrm{TNF} \alpha$ from $60-120 \mathrm{~min}$ with 90 min. being the maximum time of release. IL-1 under similar conditions was released from $\mathrm{P} 388 \mathrm{D} 1$ with the peak elevation being at 5 $\mathrm{hr}$. The IL-1 levels remainder elevated through $8 \mathrm{hr}$. and then fell slowly back to normal levels. Thus, the following biochemical parameters were measured in the presence of the amine-carboxyboranes at these peak times of the two cytokines.

Incubation of 125 I-TNF $\alpha$ with UMR-106 cells showed peak high affinity binding at $90 \mathrm{~min}$. [Table $1 \mathrm{a}$ and b]. Compound 1 at $10 \mu \mathrm{M}$ at $60 \mathrm{~min}$ caused at $34 \%$ reduction in the high affinity binding of TNF $\alpha$ whereas Compounds $\underline{2}$ and $\underline{3}$ caused $18 \%$ and $33 \%$ reduction in binding at $90 \mathrm{~min}$. When higher concentration of the drugs were employed at $90 \mathrm{~min}$ incubation, elevated high affinity binding of TNF $\alpha$ to UMR-106 receptors was observed [Table 1b].

Table 1a. The Effect of Amine-carboxyboranes at $10 \mu \mathrm{M}$ on TNFO High Affinity Receptor Binding on UMR-106 Cells 8 of Control $(N=6)$

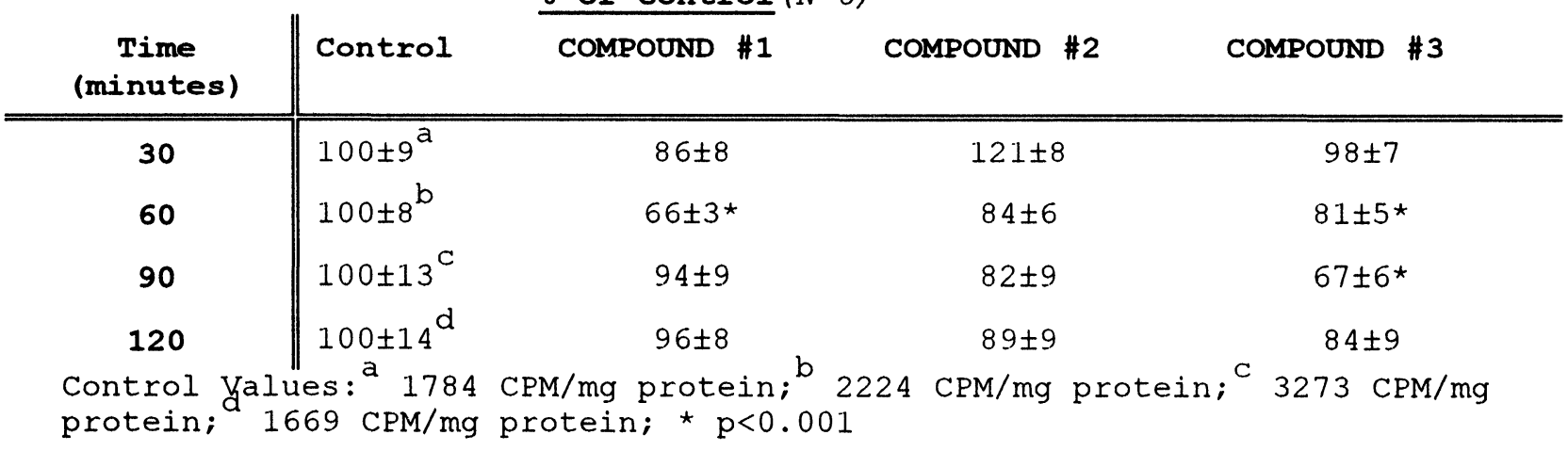

Table 1b. The Effect of Amine-carboxyboranes on TNFa High Affinity Receptor Binding on UMR-106 Cells After 90 Minutes 8 of Control $(N=6)$

\begin{tabular}{|c|c|c|c|}
\hline $\begin{array}{l}\text { Conc. } \\
\text { ( } \mu \mathrm{M})\end{array}$ & COMPOUND \#1 & COMPOUND \#2 & COMPOUND \#3 \\
\hline 12.5 & $129 \pm 9 *$ & $116 \pm 13 * \star$ & $153 \pm 17$ * \\
\hline 25 & $96 \pm 4$ & $164 \pm 8$ * & $160 \pm 11$ * \\
\hline 50 & $108 \pm 11$ & $147 \pm 15 *$ & $217 \pm 10$ * \\
\hline
\end{tabular}


125 I-IL-1 high affinity binding to UMR-106 cells peaked at $5 \mathrm{hr}$. 1815 $\mathrm{cpm} / \mathrm{mg}$ protein) and was sti.l high at $8 \mathrm{hr}$. $(742 \mathrm{cpm} / \mathrm{mg}$ protein) [Table 2a]. When the agents were incubated with labeled IL-1, at $5 \mathrm{hr}$. the concentration of $12.5 \mu \mathrm{M}$ afforded the maximum reduction for all three agents [Table 2b]. Concentrations of 25 and $50 \mu \mathrm{M}$ of the agents were less effective in reducing the binding of IL-1 to its receptor. 125 IIL-8 high affinity binding to CHO-KI membrane receptors was maximum at $24 \mathrm{hr}$. This binding was suppressed approximately 46-49\% by all three agents at $50 \mu \mathrm{M}$ [data not shown] and 125 -IL-2 high affinity binding to HuT-8 cells receptors was suppressed at 25 and $50 \mu \mathrm{M}$ of the agents at 90 $\mathrm{min}$ and at $5 \mathrm{hr}$. [Tables $2 \mathrm{c}$ and $\mathrm{d}$ ].

Table 2a. The Effect of Amine-carboxyboranes at $10 \mu \mathrm{M}$ on IL-1 High Affinity Receptor Binding on UMR-106 Cells 8 of Control $(N=6)$

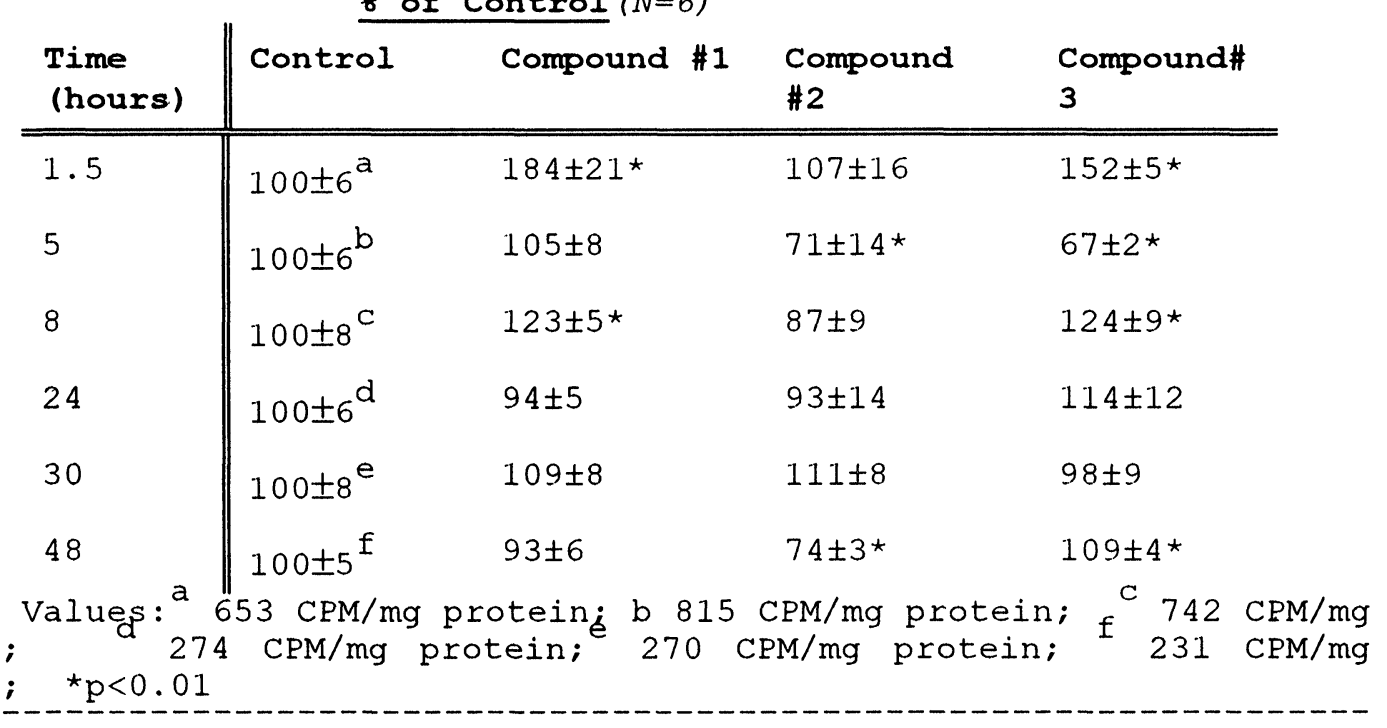

125 I-Calcitonin high affinity binding to UMR-106 cell receptors was the highest from 60 to $120 \mathrm{~min}$. and then declined. Compound 1 at $10 \mu \mathrm{M}$ caused a $38 \%$ reduction of calcitonin binding at $60 \mathrm{~min}$. and a 518 reduction at $8 \mathrm{hr}$. [Table 3]. Compound 2 at $10 \mu \mathrm{M}$ caused a $45 \%$ and $64 \%$ reduction at 5 and $8 \mathrm{hr} .$, respectivel $\bar{y}$ and Compound 3 caused a $45 \%$ reduction at $5 \mathrm{hr}$.

Table 2b. The Effect of Amine-carboxyboranes on IL-1 High Affinity Receptor Binding on UMR-106 Cells After 5 Hours 8 of Control $(N=6)$

\begin{tabular}{l||ccc}
$\begin{array}{l}\text { Conc. } \\
(\mu \mathrm{M})\end{array}$ & COMPOUND \#1 & COMPOUND \#2 & COMPOUND \#3 \\
\hline \hline 12.5 & $37 \pm 3^{\star}$ & $64 \pm 5^{\star}$ & $47 \pm 8^{\star}$ \\
25 & $59 \pm 6^{\star}$ & $89 \pm 9$ & $68 \pm 6^{\star}$ \\
50 & $68 \pm 8^{\star}$ & $75 \pm 5^{\star}$ & $82 \pm 7^{\star}$ \\
Control $=100 \pm 6 \%$ & $(581.2 \mathrm{CPM} / \mathrm{mg}$ protein $) ; * p<0.0001$ &
\end{tabular}




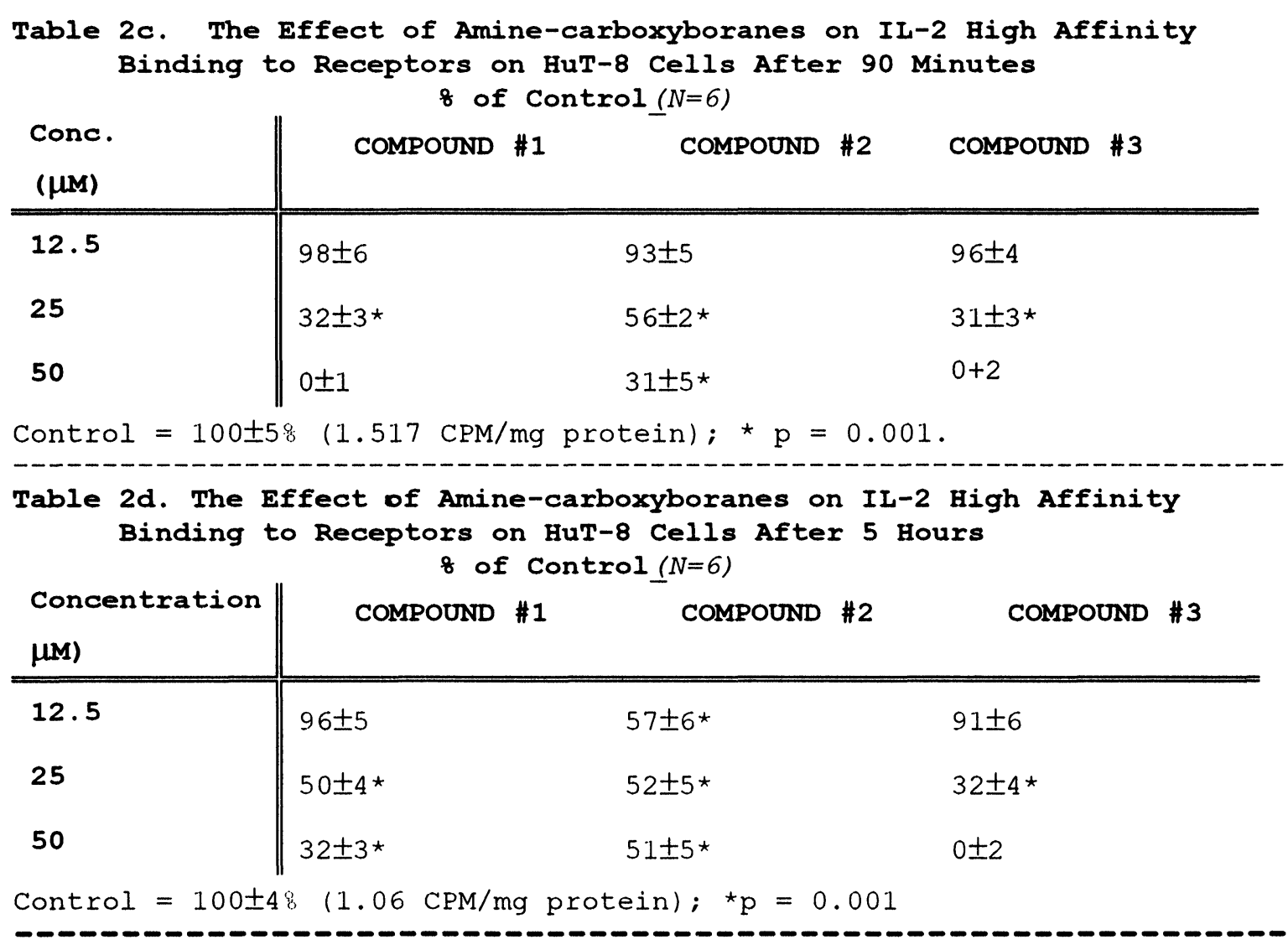

Table 3. The Effect of Amine-carboxyboranes at $10 \mu \mathrm{M}$ on Calcitonin High Affinity Binding to Receptors on UMR-106 Cells 8 of Control $(N=8)$

\begin{tabular}{l||llll}
\multicolumn{1}{l|}{$\begin{array}{l}\text { Time } \\
\text { (hours) }\end{array}$} & Control & $\begin{array}{l}\text { Compound } \\
\# 1\end{array}$ & $\begin{array}{l}\text { Compound } \\
\# 2\end{array}$ & Compound \#3 \\
\hline $\mathbf{1}$ & $100 \pm 11^{\mathrm{a}}$ & $62 \pm 5^{\star}$ & $105 \pm 8$ & $105 \pm 10$ \\
$\mathbf{1 . 5}$ & $100 \pm 14^{\mathrm{b}}$ & $78 \pm 25 \mathrm{~b}$ & $93 \pm 11$ & $85 \pm 11$ \\
$\mathbf{2}$ & $100 \pm 8^{\mathrm{C}}$ & $83 \pm 16$ & $80 \pm 16$ & $74 \pm 14^{\star}$ \\
$\mathbf{5}$ & $100 \pm 8^{\mathrm{d}}$ & $98 \pm 2$ & $55 \pm 12^{\star}$ & $55 \pm 9 \star$ \\
$\mathbf{8}$ & $100 \pm 7^{\mathrm{e}}$ & $49 \pm 6^{\star}$ & $36 \pm 8 *$ & $88 \pm 14$ \\
$\mathbf{2 4}$ & $100 \pm 9^{\mathrm{f}}$ & $97 \pm 4$ & $88 \pm 13^{\star}$ & $87 \pm 19$ \\
$\mathbf{3 0}$ & $100 \pm 9^{\mathrm{g}}$ & $96 \pm 12$ & $122 \pm 6$ & $89 \pm 19$ \\
$\mathbf{4 2}$ & $100 \pm 16^{\mathrm{h}}$ & $80 \pm 15^{\star}$ & $83 \pm 15$ & $120 \pm 17$ \\
$\mathbf{4 8}$ & $100 \pm 7^{\mathrm{i}}$ & $127 \pm 16^{\star}$ & $78 \pm 23$ & $126 \pm 16$
\end{tabular}


Control yalues: ${ }^{\mathrm{a}} 1954 \mathrm{CPM} / \mathrm{mg}$ protein; ${ }^{\mathrm{b}} 2020 \mathrm{CPM} / \mathrm{mg}$ protein; ${ }^{\mathrm{C}} 1940 \mathrm{CPM} / \mathrm{mg}$

protein; $1753 \mathrm{CPM} / \mathrm{mg}$ protein; $1520 \mathrm{CPM} / \mathrm{mg}$ protein; f $1793 \mathrm{CPM} / \mathrm{mg}$

protein; ${ }_{933} \mathrm{CPM} / \mathrm{mg}$ protein; $826 \mathrm{CPM} / \mathrm{mg}$ protein; $1447 \mathrm{CPM} / \mathrm{mg}$

protein; ${ }^{\star} \mathrm{p}<0.001$.

1,25-Dihydroxyvitamin-D high affinity binding to UMR-106 nuclear receptors was elevated by Compound 1 at $10 \mu \mathrm{M}$ at $8 \mathrm{hr}$. and Compound $\underline{3}$ caused significant elevations at 8,24 and $30 \mathrm{hr}$. [Table $4 \mathrm{a}$ ]. Higher concentrations of the agents had little effects on the elevations and in fact at $50 \mu \mathrm{M}$ at $5 \mathrm{hrs}$. the Compounds actually caused a significant reduction in binding [Table $4 \mathrm{~b}$ and $4 \mathrm{c}$ ]. TNF $\alpha$ at 10 and $100 \mathrm{ng} / \mathrm{ml}$ at 90 min caused at 26 and $20 \%$ elevation in binding of 1,25-dihydrovitamin- $\mathrm{D}_{3}$ to its nuclear receptor in UMR-106 cells.

Table 4a. The Effect of Amine-carboxyboranes at $10 \mu \mathrm{M}$ on DHD High Affinity Binding to Nuclear Receptors in UMR-106 Cells

$$
8 \text { of Control }(N=8)
$$

\begin{tabular}{|c|c|c|c|c|c|c|c|}
\hline & $\begin{array}{c}\text { Time } \\
\text { (hours) }\end{array}$ & Control & $\begin{array}{l}\text { Compound } \\
\# 1\end{array}$ & Compounc & $d \# 2$ & Compound \#3 & \\
\hline & 1.5 & $100 \pm 5^{a}$ & $118 \pm 17$ & $118 \pm 5$ & & $128 \pm 9 *$ & \\
\hline & 5 & $100 \pm 9^{b}$ & $117 \pm 10$ & $114 \pm 11$ & & $98 \pm 19$ & \\
\hline & 8 & $100 \pm 8^{c}$ & $169 \pm 6^{\star}$ & $115 \pm 10$ & & $166 \pm 16^{\star}$ & \\
\hline & 24 & $100 \pm 6^{d}$ & $129 \pm 16$ & $105 \pm 23$ & & $223 \pm 11 *$ & \\
\hline & 30 & $100 \pm 6^{e}$ & $122 \pm 9$ & $110 \pm 19$ & & $151 \pm 17^{\star}$ & \\
\hline & 48 & $100 \pm 8^{f}$ & $111 \pm 13$ & $119 \pm 15$ & & $102 \pm 7$ & \\
\hline $\begin{array}{l}\text { Control } \\
\mathrm{DPM} / \mathrm{mg} \\
\mathrm{DPM} / \mathrm{mg}\end{array}$ & $\begin{array}{l}\text { Values: } \\
\text { protein; } \\
\text { protein; }\end{array}$ & $\begin{array}{r}2143 \text { DP } \\
1333 \text { DPI } \\
\star \mathrm{d}<0.0001\end{array}$ & $\begin{array}{l}\text { mg protein; } \\
\text { mg protein; }\end{array}$ & $\begin{array}{l}b^{b} 2475 \\
e^{1393}\end{array}$ & $\begin{array}{l}\mathrm{DPM} / \mathrm{mg} \\
\mathrm{DPM} / \mathrm{mg}\end{array}$ & $\begin{array}{l}\text { protein; } \\
\text { grotein; }\end{array}$ & $\begin{array}{r}C_{1812} \\
\mathrm{f} \\
1355\end{array}$ \\
\hline
\end{tabular}

Calcium uptake by UMR-106 cells peaked at $90 \mathrm{~min}$. and then gradually declined over the next $48 \mathrm{hr}$. Incubation of the drug at $10 \mu \mathrm{M}$ [Table $5 a]$ indicated that calcium uptake was markedly reduced at $90 \mathrm{~min}$. and that $T N F \alpha$ at $10 \mathrm{ng} / \mathrm{ml}$ also caused a significant reduction of $56 \%$ whereas at $100 \mathrm{ng} / \mathrm{ml}$ TNF $\alpha$ caused only a $6 \%$ reduction at $90 \mathrm{~min}$. [data not shown]. 
Table 4b. The Effect of Amine-carboxyboranes at $100 \mu \mathrm{M}$ on DHD High Affinity Binding to Nuclear Receptors in UMR-106 Cells

\begin{tabular}{|c|c|c|c|c|}
\hline $\begin{array}{c}\text { Time } \\
\text { (hours) }\end{array}$ & Control & $\begin{array}{l}\text { Compound } \\
\# 1\end{array}$ & Compound \#2 & Compound\# 3 \\
\hline 1 & $100 \pm 17^{\mathrm{a}}$ & $105 \pm 9$ & $101 \pm 6$ & $108 \pm 6$ \\
\hline 1.5 & $100 \pm 5^{b}$ & $83 \pm 13$ & $86 \pm 8$ & $94 \pm 15$ \\
\hline 2 & $100 \pm 19^{C}$ & $75 \pm 13 \star$ & $90 \pm 18$ & $115 \pm 8$ \\
\hline 5 & $100 \pm 9^{d}$ & $115 \pm 23$ & $103 \pm 8$ & $130 \pm 22 \star \star$ \\
\hline 8 & $100 \pm 8^{e}$ & $72 \pm 26 \star \star$ & $95 \pm 6$ & $106 \pm 16$ \\
\hline 24 & $100 \pm 6^{f}$ & $111 \pm 11$ & $103 \pm 13$ & $105 \pm 3$ \\
\hline 42 & $100 \pm 14^{9}$ & $111 \pm 18$ & $96 \pm 5$ & $99 \pm 11$ \\
\hline 48 & $100 \pm 8^{h}$ & $128 \pm 29$ & $99 \pm 11$ & $110 \pm 19$ \\
\hline
\end{tabular}

Control Values: ${ }^{a}$ d1329 DPM/mg protein; b 2143 DPM/mg protein; C 220 q $\mathrm{DPM} / \mathrm{mg}$ protein; $2475 \mathrm{DPM} / \mathrm{mg}$ protein; $\mathrm{h} 1812 \mathrm{DPM} / \mathrm{mg}$ protein; $1333 \mathrm{DPM} / \mathrm{mg}$ protein; $1302 \mathrm{CPM} / \mathrm{mg}$ protein; $1355 \mathrm{CPM} / \mathrm{mg}$ protein; $\star \mathrm{p}<0.0001 ; \star \star \mathrm{p}<0.025$.

Table 4c. The Effect of Amine-carboxyboranes on DHD High Affinity Binding to Nuclear Receptors in UMR-106 Cells After 5 Hours 8 of Control $(N=8)$

\begin{tabular}{|c|c|c|c|}
\hline \multirow[b]{2}{*}{$\begin{array}{l}\text { Concentration } \\
(\mu \mathrm{M})\end{array}$} & \multicolumn{2}{|c|}{8 of Control } & \multirow[b]{2}{*}{ COMPOUND \#3 } \\
\hline & COMPOUND \#1 & COMPOUND \#2 & \\
\hline 10 & $117 \pm 10$ & $114 \pm 11$ & $98 \pm 19$ \\
\hline 12.5 & $73 \pm 19 \star$ & $91 \pm 8$ & $87 \pm 17$ \\
\hline 25 & $70 \pm 23 \star$ & $80 \pm 17 \star \star$ & $74 \pm 13 *$ \\
\hline 50 & $53 \pm 16 \star$ & $77 \pm 14^{\star}$ & $53 \pm 23 *$ \\
\hline 100 & $115 \pm 23$ & $103 \pm 8$ & $130 \pm 22$ \\
\hline
\end{tabular}

Reduction of calcium uptake by UMR-106 cells peaked at $90 \mathrm{~min}$. and then gradually the agents at $10 \mu \mathrm{M}$ reversed the suppression of calcium influx over time. At 8 and $12 \mathrm{hr}$. the agents caused a significant elevation in calcium uptake but from 18 to $48 \mathrm{hr}$. The influx of calcium into bone cells was reduced. Calcium uptake into UMR-106 cells after a $5 \mathrm{hr}$. incubation, fell at $10 \mu \mathrm{M}$ but at higher concentration of the agents there was an elevation in calcium uptake. Compound 1 doubled the calcium uptake at $25 \mu \mathrm{M}$ but fell at $50 \mu \mathrm{M}$ [Table 5b]. Compound 2 caused a doubling of calcium uptake at $5 \mathrm{hr}$. at 25 and $50 \mu \mathrm{M}$. Compound $\underline{3}$ was less effective and showed 98 and $12 \%$ increases at 25 and $50 \mu \mathrm{M}$, respectively. 
Table 5a. The Effect of Amine-carboxyboranes at $10 \mu \mathrm{M}$ on Calcium

uptake into UMR-106 Cells

8 of Control $(N=8)$

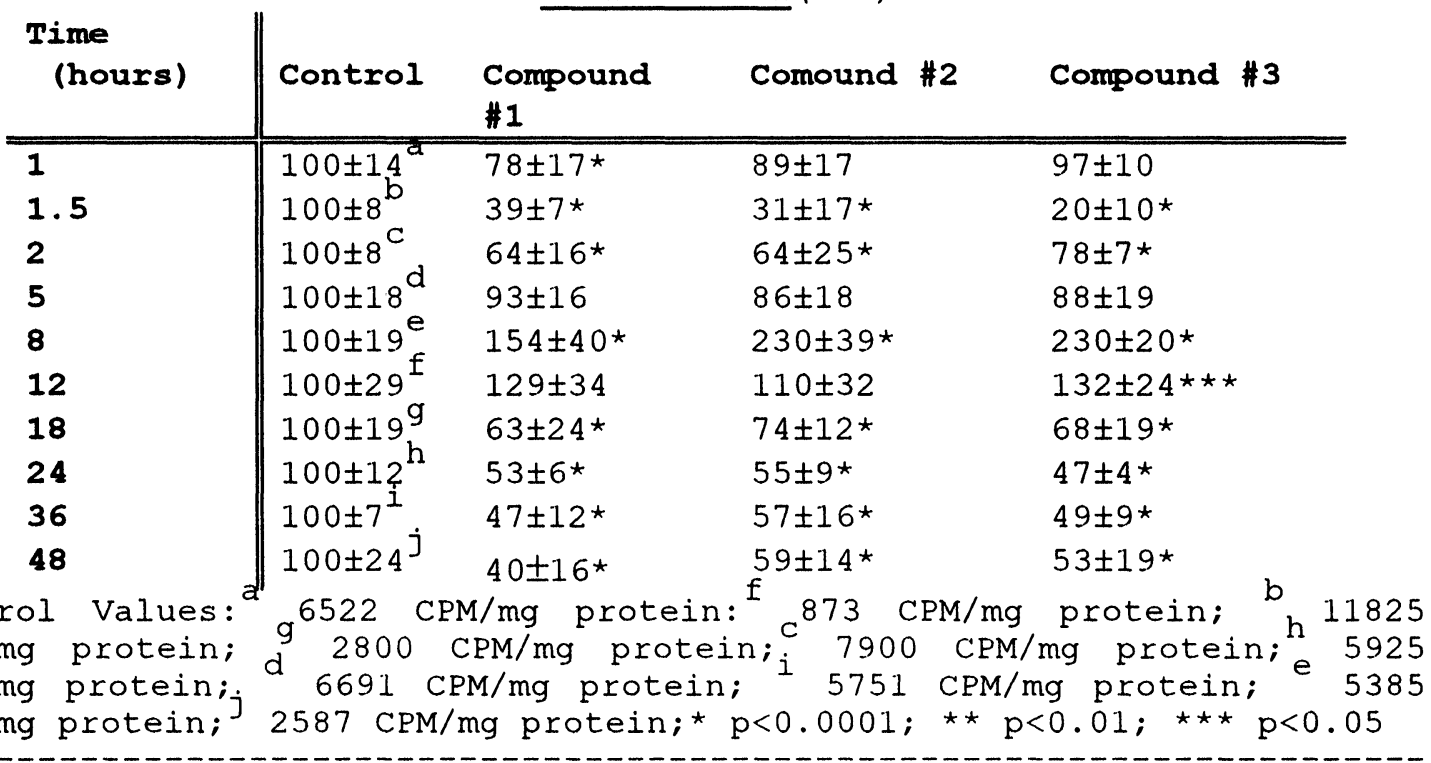

Table 5b. The Effect of Amine-carboxyboranes on Calcium Uptake into UMR106 Cells After 5 Hours

8 of Control $(N=8)$

\begin{tabular}{|c|c|c|c|c|}
\hline Concentration ( $\mu M)$ & COMPOUND \#1 & COMPOUND \#2 & COMPOUND & $\# 3$ \\
\hline 10 & $93 \pm 16$ & $86 \pm 18 * \star \star \star$ & $88 \pm 19$ & \\
\hline 12.5 & $111 \pm 10 \star \star \star$ & $123 \pm 2$ * & $109 \pm 10 * \star \star \star x$ & \\
\hline 25 & $193 \pm 10 \star$ & $207 \pm 8$ * & $112 \pm 9 \star \star$ & \\
\hline 50 & $84 \pm 8$ * & $214 \pm 10 *$ & $65 \pm 6 *$ & \\
\hline $\begin{array}{l}\text { Control }=100 \pm 9 \quad(14,50 \\
p<0.025 ; * \star \star \star p \\
p<0.05\end{array}$ & 0 CPM/mg protein); * & $\mathrm{p}<0.0001 ; \star \star \star$ & $\mathrm{p}<0.01 ;$ & $\star \star \star$ \\
\hline
\end{tabular}

Proline incorporation into collagen of UMR-106 cells followed a time dependent effect over $48 \mathrm{hr}$. [Table 6a]. The agents at $10 \mu \mathrm{M}$ caused a significant increase in proline incorporation at 5 and $8 \mathrm{hr}$. but not at 24 and $48 \mathrm{hr}$. Proline incorporation into non-collagen protein of UMR106 cells was elevated only at $8 \mathrm{hr}$. by Compounds $\underline{1}$ and $\underline{2}$ [Table 6b]. Compound $\underline{2}$ at $12.5,25$ and $50 \mu \mathrm{M}$ markedly elevated proline incorporation whereas Compounds $\underline{1}$ and $\underline{3}$ had no effect or actually reduced incorporation at $12.5 \mu \mathrm{M}$. [Table 6c]. Non-collagen incorporation of proline was not affected by the higher concentrations of any of the agents [Table 6d]. TNFo at $100 \mathrm{ng} / \mathrm{ml}$ at $5 \mathrm{hr}$. caused a $49 \%$ increase of proline incorporation into collagen but at $10 \mathrm{ng} / \mathrm{ml}$ had no affect at 90 min. or $5 \mathrm{hr}$. nor was there any effect on the non-collagen incorporation. 
Table 6a. The Effect of Amine-carboxyboranes at $10 \mu \mathrm{M}$ on Proline Incorporation into Collagen in UMR-106 Cells 8 of Control $(N=6)$

\begin{tabular}{|c|c|c|c|c|}
\hline $\begin{array}{l}\text { Time } \\
\text { (hours) }\end{array}$ & Control & COMPOUND \#1 & COMPOUND \#2 & COMPOUND \#3 \\
\hline 1.5 & $100 \pm 11^{a}$ & $115 \pm 8 * \star$ & $98 \pm 9$ & $116 \pm 10 \star \star$ \\
\hline 5 & $100 \pm 14^{b}$ & $207 \pm 7 *$ & $142 \pm 21 \star$ & $203 \pm 11$ * \\
\hline 8 & $100 \pm 8^{c}$ & $544 \pm 4$ * & $271 \pm 27 \star$ & $363 \pm 27 \star$ \\
\hline 24 & $100 \pm 8^{d}$ & $69 \pm 10 *$ & $93 \pm 5 \star \star \star$ & $84 \pm 7 *$ \\
\hline 48 & $100 \pm 7^{e}$ & $57 \pm 6 *$ & $101 \pm 21$ & $69 \pm 24 *$ \\
\hline
\end{tabular}

Control values:a $4844 \mathrm{DPM} / \mathrm{ml} ; \mathrm{b} 5113 \mathrm{DPM} / \mathrm{ml} ; \mathrm{C} 6986 \mathrm{DPM} / \mathrm{ml} ; \mathrm{d} 9396$ $\mathrm{DPM} / \mathrm{ml} ;$ e $13595 \mathrm{DPM} / \mathrm{ml} ; * \quad \mathrm{p}<0.0001 ; \star \star \quad \mathrm{p}<0.01 ; * \star \star \mathrm{p}<0.025$

UMR-106 NAG hydrolytic activity was not inhibited by the aminecarboxyboranes at $90 \mathrm{~min}$. or $5 \mathrm{hr}$. from 10 to $100 \mu \mathrm{M}$. Time periods of 24-72 hr. were found to be needed to observed the inhibition by the agents. Compound 3 caused $25^{\circ}$ and $31 \%$ at 24 and 48 hr., respectively at $10 \mu \mathrm{M}$. [Table 7].

Table 6b. The Effect of Amine-carboxyboranes at $10 \mu \mathrm{M}$ on Proline Incorporation into Non-Collagen in UMR-106 Cells

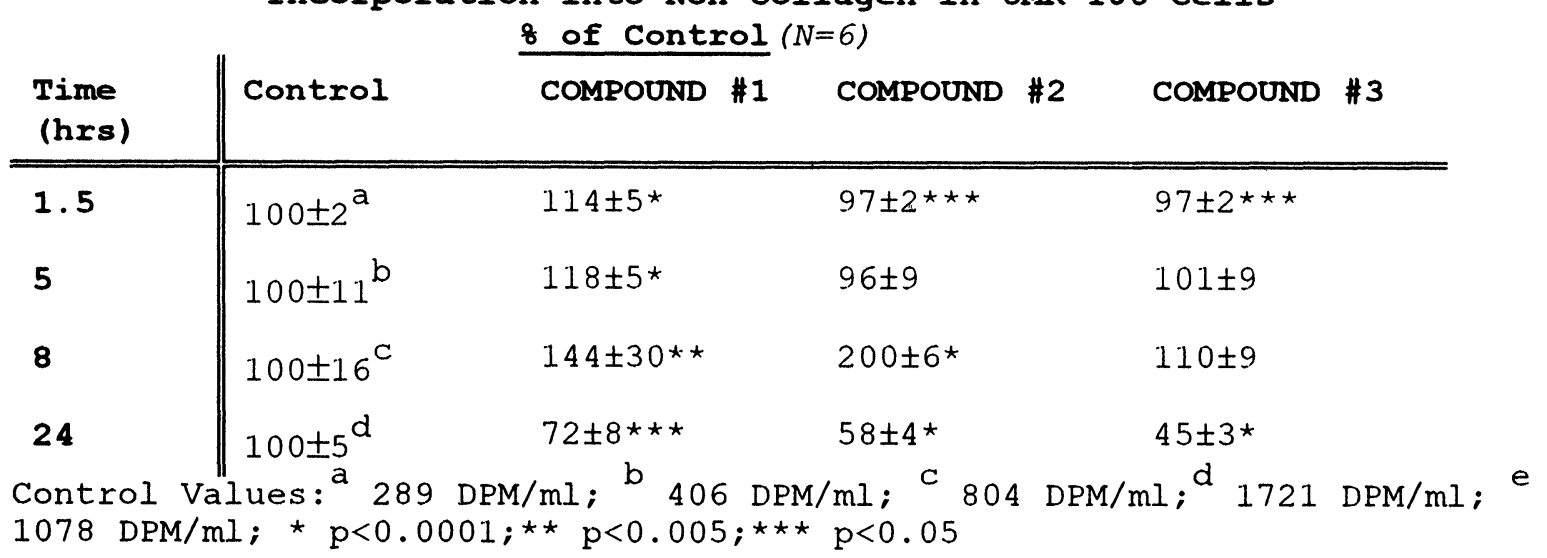

Table 6c The Effect of Amine-carboxyboranes on Proline Incorporation into Collagen in UMR-106 Cells After 5 Hours

\begin{tabular}{|c|c|c|c|}
\hline $\begin{array}{l}\text { Concentration } \\
(\mu M)\end{array}$ & COMPOUND \#1 & COMPOUND \#2 & COMPOUND \#3 \\
\hline 12.5 & $62 \pm 13 \star$ & $279 \pm 15^{\star}$ & $63 \pm 5 \star$ \\
\hline 25 & $93 \pm 9$ & $229 \pm 13 *$ & $81 \pm 7$ * \\
\hline 50 & $95 \pm 25$ & $199 \pm 18$ * & $77 \pm 16 * \star$ \\
\hline
\end{tabular}

Control $=100 \pm 128(2380 \mathrm{DPM} / \mathrm{ml}) ; * \quad \mathrm{p}<0.0001 ; * \star \mathrm{p}<0.005$ 
Compound 2 caused a $36 \%$ reduction and Compound 1 caused a 258 reduction at $10 \mu \mathrm{M}$ after $48 \mathrm{hr}$. The acid and akaline phosphatase activities in UMR-106 cells were significantly reduced in the presence of the aminecarboxyboranes from 12.5 to $50 \mu \mathrm{M}$ at $90 \mathrm{min.} 5$ and $18 \mathrm{hrs}$. [Tables $8 \mathrm{a}-\mathrm{c}$ and $9 \mathrm{a}-\mathrm{c}]$.

\begin{tabular}{|c|c|c|c|}
\hline $\begin{array}{l}\text { Concentration } \\
(\mu \mathrm{M})\end{array}$ & COMPOUND \#1 & COMPOUND \#2 & COMPOUND \#3 \\
\hline 12.5 & $108 \pm 10 \star \star \star$ & $124 \pm 8 *$ & $120 \pm 4$ * \\
\hline 25 & $86 \pm 8 * \star$ & $94 \pm 4 \star \star \star$ & $84 \pm 3^{\star}$ \\
\hline 50 & $96 \pm 2$ & $84 \pm 6$ & $108 \pm 8 * \star \star$ \\
\hline
\end{tabular}

\begin{tabular}{|c|c|c|c|c|c|c|c|}
\hline \multirow{3}{*}{$\begin{array}{l}\text { Time } \\
\text { (hours) }\end{array}$} & \multirow{3}{*}{ Control } & \multicolumn{3}{|c|}{$\begin{array}{l}\text { ity in UMR-106 } \\
8 \text { of Control }\end{array}$} & \multirow[t]{2}{*}{$\begin{array}{l}\text { Cells } \\
(N=8)\end{array}$} & \multirow{2}{*}{\multicolumn{2}{|c|}{ CMPD \#3 }} \\
\hline & & CMPD \#1 & & CMPD \#2 & & & \\
\hline & & $1 \mu \mathrm{M}$ & $10 \mu \mathrm{M}$ & $1 \mu \mathrm{M}$ & $10 \mu \mathrm{M}$ & $1 \mu \mathrm{M}$ & $10 \mu \mathrm{M}$ \\
\hline 24 & $100 \pm 5^{a}$ & $125 \pm 14^{\star}$ & $130 \pm 10^{*}$ & $105 \pm 6$ & $104 \pm 4$ & $93 \pm 5 *$ & $75 \pm 13 *$ \\
\hline 48 & $100 \pm 6^{b}$ & $81 \pm 6^{\star}$ & $75 \pm 12$ * & $86 \pm 4$ * & $64 \pm 4$ * & $81 \pm 5 *$ & $69 \pm 5 *$ \\
\hline 72 & $100 \pm 4^{\mathrm{C}}$ & $88 \pm 5 \star$ & $103 \pm 8$ & $114 \pm 5 \star$ & $87 \pm 5 \star$ & $95 \pm 5$ & $88 \pm 6 *$ \\
\hline
\end{tabular}

Control Values: a 12 nmoles p-nitrophenol released/ml medium; 39 nmoles p-nitrophenol released/ml medium; 40 nmoles $p$-nitrophenol released/ml mediu; * $p<0.0001$

Table 8a. The Effect of Amine-carboxyboranes on Acid Phosphatase Activity in UMR-106 Cells After 90 Minutes

\begin{tabular}{|c|c|c|c|}
\hline $\begin{array}{l}\text { Concentration } \\
(\mu \mathrm{M})\end{array}$ & COMPOUND \#1 & COMPOUND \#2 & COMPOUND \# \\
\hline 12.5 & $51 \pm 3 *$ & $56 \pm 5 \star$ & $51 \pm 5 *$ \\
\hline 25 & $28 \pm 4$ * & $30 \pm 7 \star$ & $30 \pm 3^{\star}$ \\
\hline 50 & $26 \pm 3^{\star}$ & $20 \pm 3 *$ & $25 \pm 4$ * \\
\hline
\end{tabular}




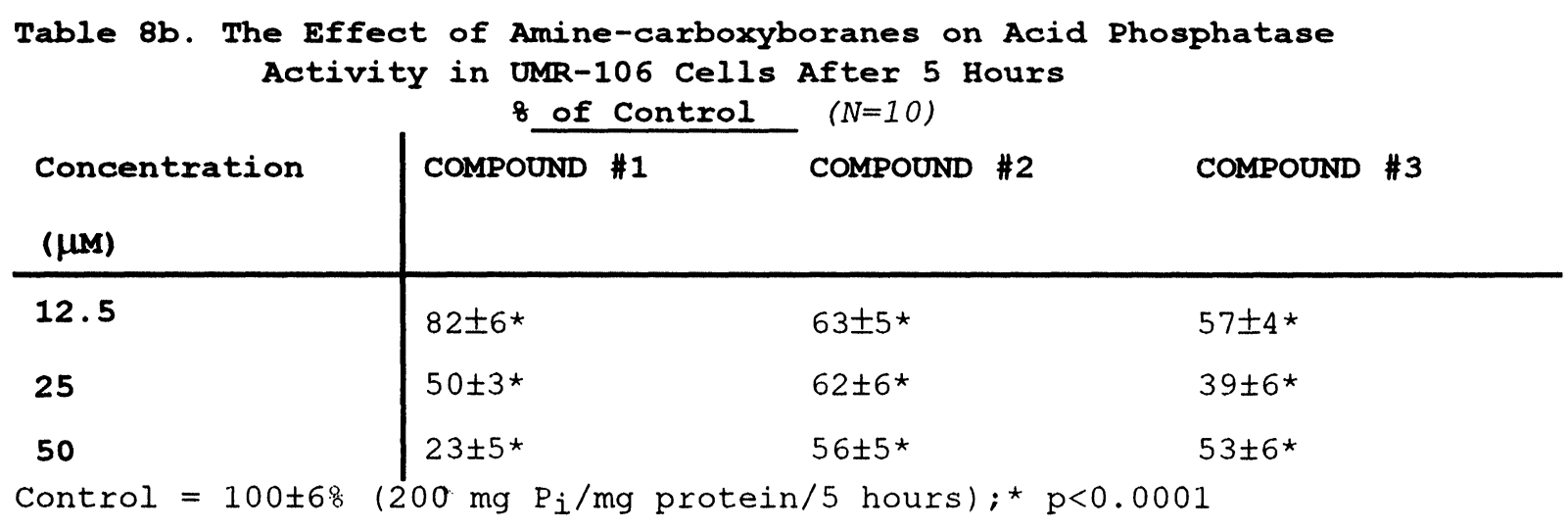

Table 8c Effect of Amine-carboxyboranes on Acid Phosphatase Activity in UMR-106 Cells After 18 Hours

\begin{tabular}{|c|c|c|c|}
\hline $\begin{array}{l}\text { Concentration } \\
(\mu \mathrm{M})\end{array}$ & COMPOUND \#1 & COMPOUND \#2 & COMPOUND \#3 \\
\hline 12.5 & $80 \pm 7 \star$ & $89 \pm 9 *$ & $86 \pm 8$ \\
\hline 25 & $61 \pm 7 *$ & $70 \pm 8 *$ & $51 \pm 5 *$ \\
\hline 50 & $43 \pm 5^{\star}$ & $43 \pm 6^{\star}$ & $16 \pm 4$ * \\
\hline
\end{tabular}

Table 9a. The Effect of Amine-carboxyboranes on Alkaline Phosphatase Activity in UMR-106 Cells After 90 Minutes

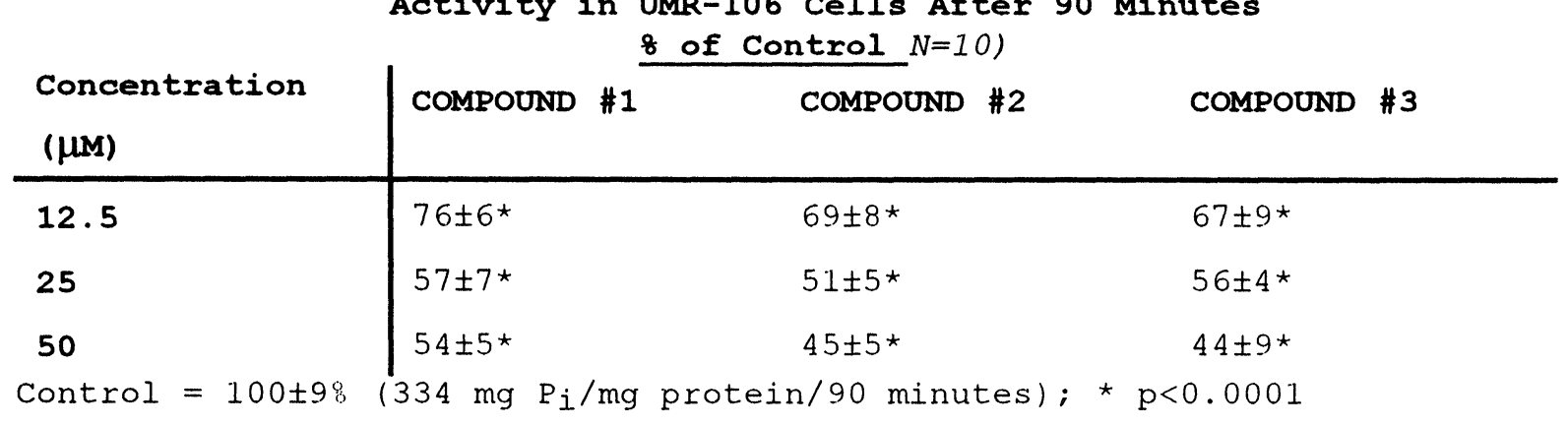

Table 9b. The Effect of Amine-carboxyboranes on Alkaline Phosphatase Activity in UMR-106 Cells After 5 Hours

\begin{tabular}{|c|c|c|c|}
\hline \multirow[b]{2}{*}{$\begin{array}{l}\text { Concentration } \\
(\mu \mathrm{M})\end{array}$} & \multicolumn{3}{|c|}{$\begin{array}{l}\text { Activity in UMR-106 Cells After } 5 \text { Hours } \\
8 \text { of Control }(N=10)\end{array}$} \\
\hline & COMPOUND \#1 & COMPOUND \#2 & COMPOUND \#3 \\
\hline 12.5 & $83 \pm 8$ & $80 \pm 9$ & $81 \pm 7$ \\
\hline 25 & $78 \pm 6^{\star}$ & $48 \pm 6^{\star}$ & $62 \pm 6^{*}$ \\
\hline 50 & $67 \pm 7^{\star}$ & $46 \pm 7^{\star}$ & $56 \pm 5 *$ \\
\hline Control $=100 \pm 7 \%$ & $700 \mathrm{mg} \mathrm{P}_{\mathrm{i}} / \mathrm{mg}$ & n/5 hours); & 0001 \\
\hline
\end{tabular}




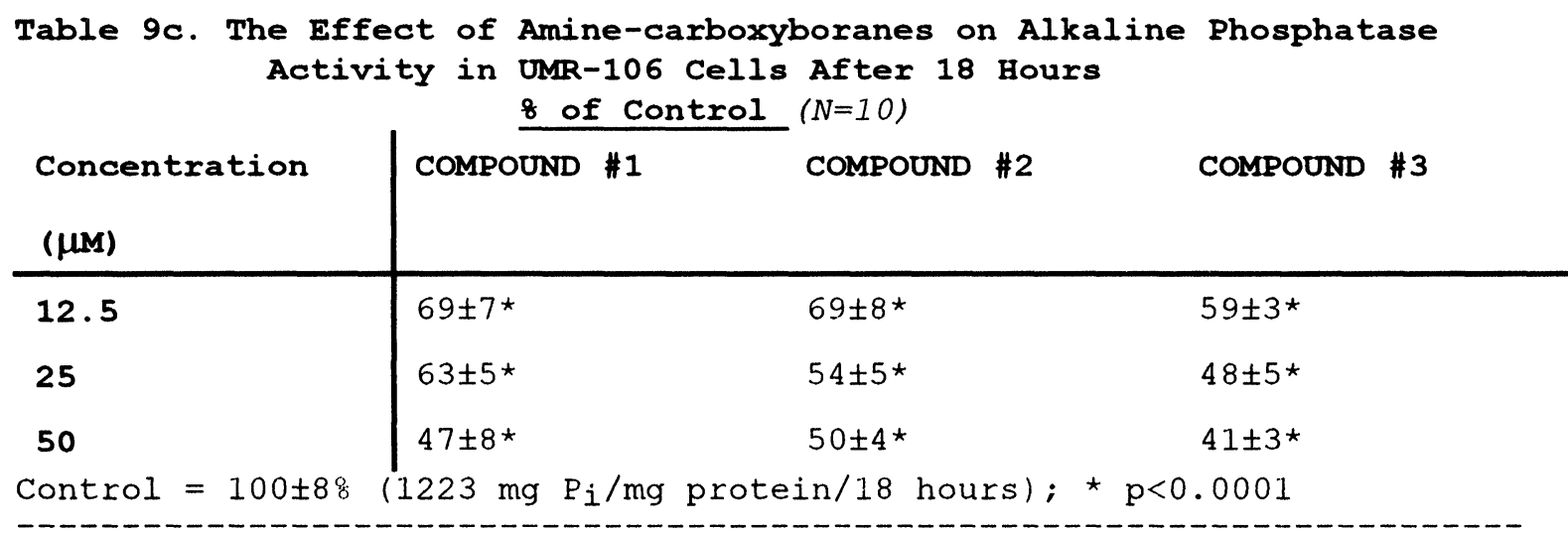

Table 10a Effect of Amine-carboxyboranes on Prostaglandin Cyclooxygenase Activity in UMR-106 Cells After 90 Minutes

\begin{tabular}{|c|c|c|c|}
\hline $\begin{array}{c}\text { Concentration } \\
(\mu \mathrm{M})\end{array}$ & COMPOUND $\# \frac{8}{1}$ & $\frac{1 \text { trol } \quad(N=6)}{\text { COMPOUND \#2 }}$ & COMPOUND \#3 \\
\hline 12.5 & $36 \pm 7^{\star}$ & $87 \pm 5$ & $52 \pm 6^{\star}$ \\
\hline 25 & $50 \pm 4$ * & $54 \pm 4$ * & $43 \pm 7 \star$ \\
\hline 50 & $35 \pm 5 *$ & $41 \pm 5^{\star}$ & $38 \pm 4$ * \\
\hline
\end{tabular}

Table 10b. The Effect of Amine-carboxyboranes on Prostaglandin Cyclooxygenase Activity in UMR-106 Cells After 5 Hours

\begin{tabular}{|c|c|c|c|}
\hline $\begin{array}{c}\text { Concentration } \\
(\mu \mathrm{M})\end{array}$ & COMPOUND \#1 & COMPOUND \#2 & COMPOUND \#3 \\
\hline 12.5 & $90 \pm 7$ & $52 \pm 4$ * & $92 \pm 6$ \\
\hline 25 & $82 \pm 6$ & $67 \pm 4$ * & $82 \pm 6$ \\
\hline 50 & $79 \pm 6 *$ & $78 \pm 5 *$ & $76 \pm 5 \star$ \\
\hline
\end{tabular}

Table 11a. The Effect of Amine-carboxyboranes on 5'-Lipoxygenase Activity in UMR-106 Cells After 90 Minutes

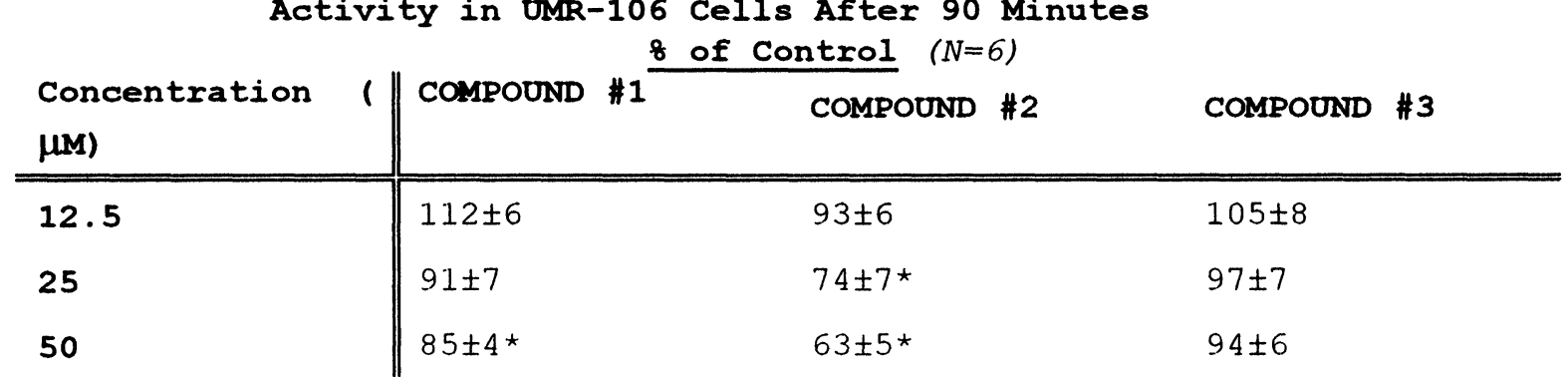

Control $=100 \pm 8 \%(2606 \mathrm{DPM} / \mathrm{mg}$ protein $) ; * \quad \mathrm{p}<0.0001$.

Whereas, UMR-106 5'-lipoxygenase activity was not inhibited significantly by the agents at $90 \mathrm{~min}$ with the exception of Compound $\underline{2}$ 
at 25 and $50 \mu \mathrm{M}$. At $5 \mathrm{hr}$. all of the compounds at $50 \mu \mathrm{M}$ caused inhibition of 5'-lipoxygenase activity [Table 1la and b].

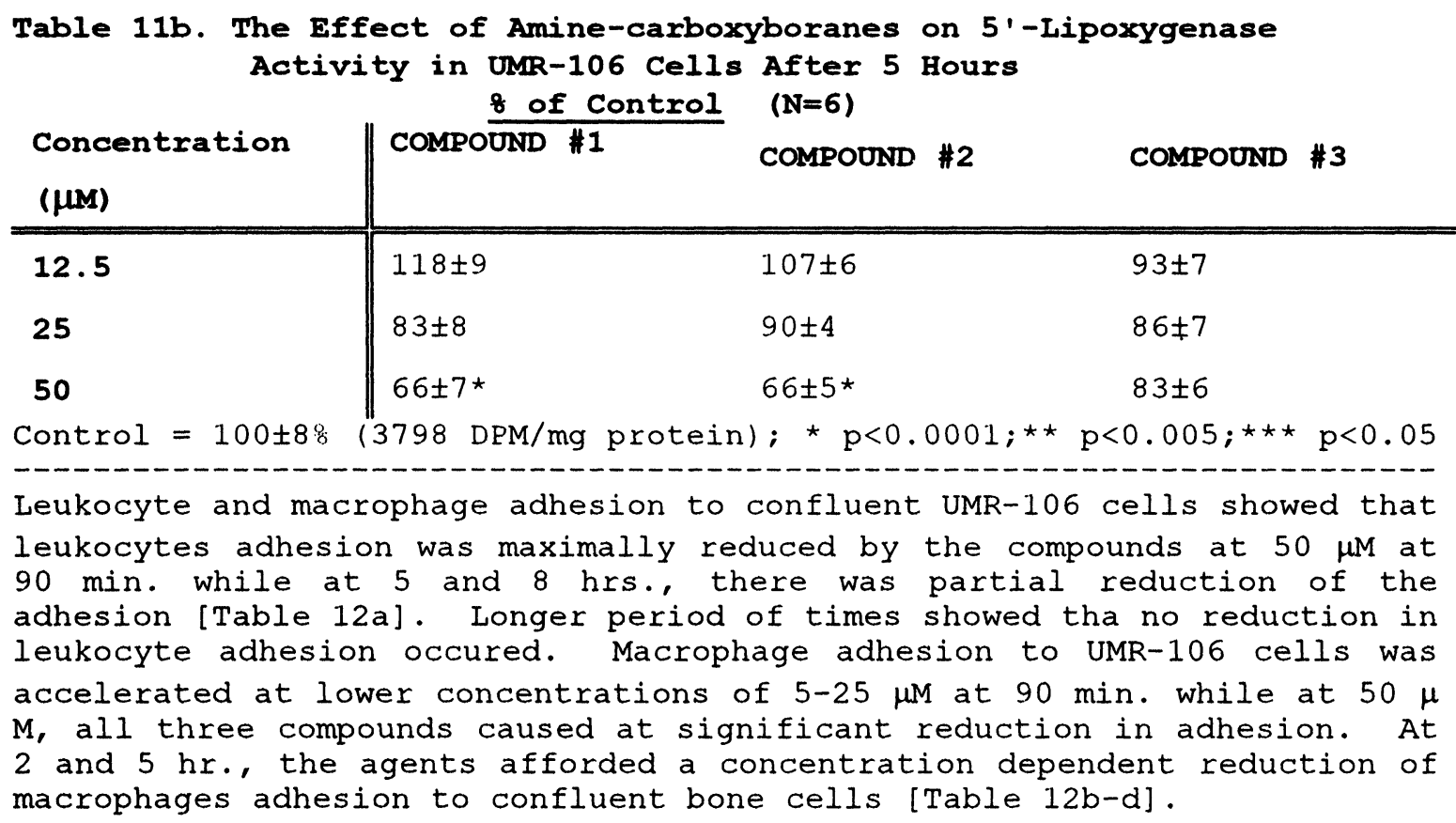

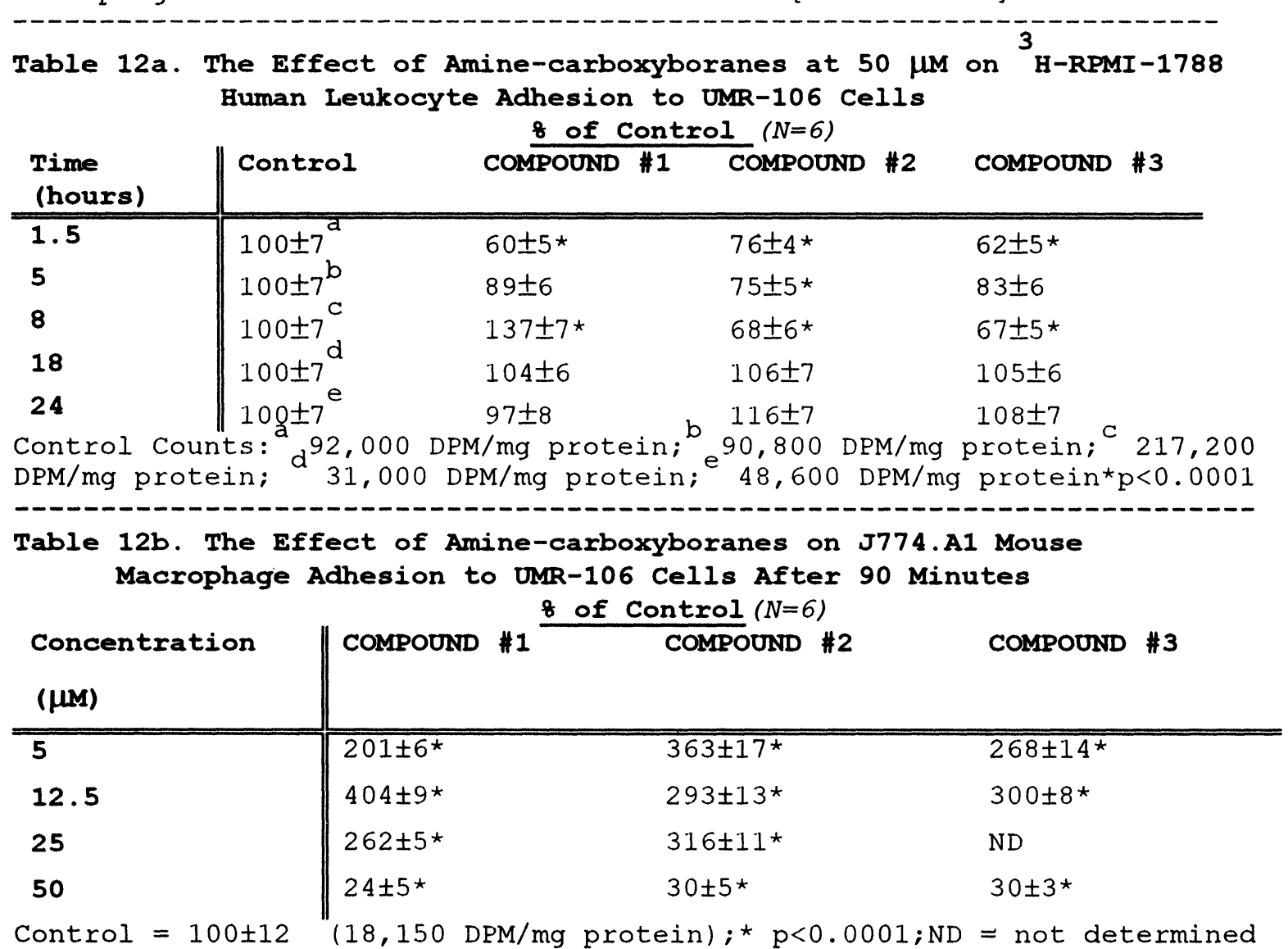




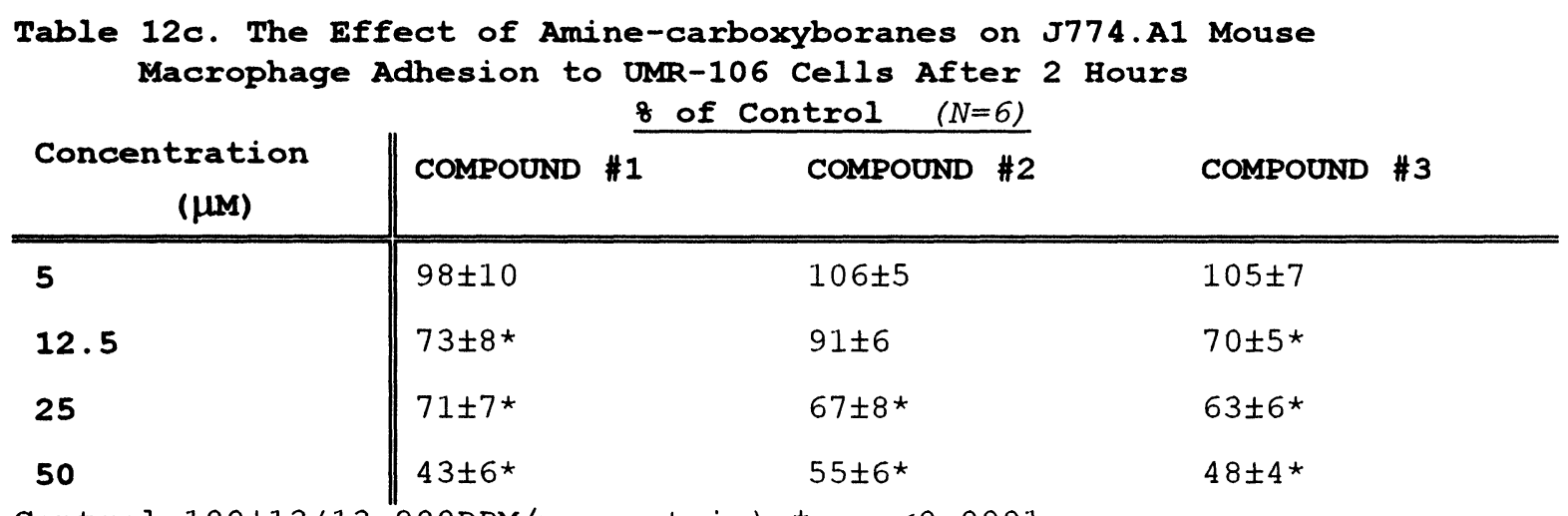

Control $=100 \pm 13(13,900 \mathrm{DPM} / \mathrm{mg}$ protein $) ;{ }^{*} \mathrm{p}=<0.0001$

Table 12d The Effects of Amine-carboxyboranes on J774. A1 Mouse Macrophage Adhesion to UMR-106 Cells After 5 Hours

\begin{tabular}{|c|c|c|c|}
\hline $\begin{array}{l}\text { Concentration } \\
(\mu \mathrm{M})\end{array}$ & COMPOUND \#1 & COMPOUND \#2 & COMPOUND \#3 \\
\hline 5 & $98 \pm 6$ & $113 \pm 9$ & $112 \pm 7$ \\
\hline 12.5 & $69 \pm 5^{\star}$ & $118 \pm 8$ & $63 \pm 6^{*}$ \\
\hline 25 & $71 \pm 6^{\star}$ & $67 \pm 5 *$ & $62 \pm 7 *$ \\
\hline 50 & $43 \pm 4$ * & $55 \pm 5$ * & $47 \pm 4$ * \\
\hline
\end{tabular}

\section{Discussion}

The destructive phase of bone osteoporosis is initiated by cytokines which are chemical cell communicators released by invading macrophages after being stimulated. Early bone resorption effects are evoked by TNF $\alpha$ whereas later effects are regulated by IL- 1 and then IL- 6 and IL8. Bone resorption is divided into two phases: phase $I$ involves inorganic demineralization of cortical bone which is a process initiated by influxing macrophages, PMNs, fibroblasts and osteoclasts, etc. and phase II is the organic phase where the bone matrix collagen is digested by proteolytic and hydrolytic enzymes to release hydroproline. Drug therapy should involve blocking the early resorption events as well as the acceleration of the reconstruction of bone.

In vivo studies with the amine-carboxyboranes at $8 \mathrm{mg} / \mathrm{kg} /$ day suggest that the calcium uptake and increase in bone collagen deposition had occurred improving the tensile strength of the bone after 14 days treatment[2]. The present studies have demonstrated that aminecarboxyboranes block TNF $\alpha$ and IL-1 release from the types of cells which invade the bone surface to begin the resorption process. Further, these studies showed that these agents also block early adhesion of these migratory cells to the bone cells from $90 \mathrm{~min}$. to $5 \mathrm{hr}$. and macrophage adhesion is blocked at 2 and $5 \mathrm{hr}$. at higher concentration of the agents. Blockage of the adhesion of these cell to the bone surface should reduce the hydrolytic and proteolytic enzymes as well as the release of cytokines into the area of the bone surface. Previous studies had demonstrated that the amine-carboxyboranes reduce the activity of macrophages lysosomal and proteolytic enzyme activites with IC-50 values $\sim 10^{-6}$ M. [1]. Furthermore the amine-carboxyboranes at 8 
$\mathrm{mg} / \mathrm{kg} /$ day were shown in vivo to block PMNs and macrophage infiltration into inflammation sites, i.e. implanted sponges[3,4]. Since bone has high affinity receptors for $T N F \alpha$ and $I L-1$ as well as other cytokines, the current studies suggest that the cytokine receptors are blocked by the amine-carboxyboranes in a range of 12.5-50 $\mu \mathrm{M}$.

Whether the compounds are able to displace labeled cytokine from the high affinity receptors because they are agonists or antagonists can not be determined by this type of study. Nevertheless, the blockage of the cytokine receptors positively correlated with certain cellular biochemical events linked with inflammation and bone resorption. For example, the agents effectively blocked bone acid and alkaline phosphatase activities as well as cyclo-oxygenase activity when TNF $\alpha$ binding was maximally reduced by the agents. This $90 \mathrm{~min}$. period also correlated with a reduction on calcium uptake by the bone cells and the lowest level of calcitonin binding to its high affinity receptor on bone cells and of 1,25-dihydro-vitamin- $D_{3}$ to its nuclear high affinity receptor.

At a later time of $5 \mathrm{hr}$., the metabolic events reverse themselves. This is at a time when IL-1 high affinity receptor binding is maximally blocked by the amine-carboxyboranes and this time period correlated with the agents inhibiting NAG activity and 5'-lipoxygenase activities as well as reducting the calcitonin high affinity receptor binding, but the 1,25-dihydro-vitamin- $\mathrm{D}_{3}$ high affinity receptor binding was elevated in the presence of the agents. This $5 \mathrm{hr}$. time period correlated with the elevated uptake of calcium into bone as well the increased incorporation of proline into bone collagen and possiblly non-collagen protein at the lower concentrations of the agents. Inhibition of IL-8 high affinity receptor by the agents occurred at a later time which positively correlated with continued calcium uptake and proline incorporation into protein between 8 and 24 hrs.

Whereas the studies were not conclusive, they did indicate that the early stages of bone resorption with tissue destruction may be regulated by TNF $\alpha$ which can be blocked by the amine-carboxyboranes. Later events regulated by IL-1 could be blocked by the agents by suppressing the high affinity binding activity leading to restoration of dense bone. These finding did support the in vivo studies with these compound in rats for 14 days and do explain why the bone restoration stage was achieved so quickly by the amine-carboxyboranes.

\section{References:}

1. I.H. Hall, K.G. Rajendran, S.Y. Chen, O.T. Wong, A. Sood, B.F. Spielvogel, Arch Pharm (Weinheim) 1995, 328, 39-44.

2. K.G. Rajendran, S.Y. Chen, A. Sood, B.F. Spielvogel, I.H. Hall. Biomed. Pharmacotherapy. 1995, in press.

3. I.H. Hall, S.Y. Chen, K.G Rajendran, A. Sood, B.F. Spielvogel, J. Shih, Environ. Health Perspect 1994, 102 (Suppl 3), 21-30.

4. I.H. Hall, C.O. Starnes, A.T. MCPhail, P. Wisian-Neilson, M.K. Das, B.F. Spielvogel, J. Pharm. Sci.1980, 69, 1025-1029.

5. F.C. Kull, Jr., Nat Immun. Cell Growth Regul. 1988, 7, 254-265.

6. F.H. Nielsen, C.D. Hunt, L.M. Mullen, J.R. Hunt, FASEB J., 1987, 1, 394-397.

7. F.H. Nielsen, L.M. Mullen, S.K. Gallagher, J. Trace Elements Exp. Med. 1990, 3, 45-54.

8. B. Peterofsky, Arch Biochem. Biophys. 1972, 152, 318-325.

9. P.S. Chen, T.Y. Toribara, and H. Warner,.. Anal. Chem.1956, 28, 17561758 . 
10. H. Tulberg-Reinert, A.F.Hefti, Agents and Actions 1977, 32, 321-332.

11. R.V. Tomlinson, R.V. Ringold, M.C. Oureshi, E. Forchieli, Biochem. Biophys. Res. Commun. 1972, 46, 552-558..

12 M. Glatt, H. Kalin, K. Wagner, K. Brune, Agents Actions 1977, 7, 321334 .

13. D.L. Flynn, T.R. Belliotti, A.M. Boctor, D.T. Connor, C.R. Kostlan, D.E., Nies, D.F. Ortwine, D.J. Schrier, J.C. Sircar, J. Med. Chem. 1991, 34, 518-525.

14. D.L. Flynn, T.Capiris, W.J. Cetenko, D.T. Connor, R.D. Dyer, C.R. Kostlan, D.E. Nies, D.J. Schrier, J.C. Sirar, J. Med. Chem., 1990, $33, \cdot 2070-2072$.

15. I.H. Hall, R. Simlot, C. Oswald, A.R.K. Murthy, H. ElSourady, J. Chapman Jr., Acta Pharm. Nord. 1990, 2, 387-400.

16. Y.H. Chin, V. Falanga, J.P.Cai, J. Invest. Dermatol. 1990, 95, 29S-31S

Received: November 7, 1995 - Accepted: December 7, 1995 Received in revised camera-ready format: January 9, 1996 